\title{
Pengaruh Konsentrasi Deterjen Pencuci Terhadap Kualitas Kain Batik
}

\author{
Puji Asih \\ Fakultas Sain danTeknologi, Program Studi Teknik Industri, Universitas Widya Mataram \\ Dalem Mangkubumen KT.III/237 Yogyakarta \\ Email: pujiasih1@yahoo.com
}

\begin{abstract}
Abstrak
Penelitian dengan Judul Pengaruh Konsentrasi Deterjen Pencuci Terhadap Kualitas Kain Batik, berjutuan untuk mengetahui adakah pengaruh konsentrasi deterjen terhadap kualitas kain batik dan sampai seberapa besar perubahan warna yang dihasilkan. Selanjutnya kualitas warna yang dihasilkan tersebut dibandingkan menurut kriteria SNI .Kain batik dilakukan proses pencucian dengan menggunakan deterjen sesuai dengan konsentrasi yang telah ditetapkan. Kain batik yang telah mengalami proses pencucian menggunakan deterjen sesuai dengan konsentrasinyang. Selajutnya kain batik dikeringkan dengan menjemur langsung di bawah sinar matahari hingga kering. Ulangi percobaan tersebut sesuai dengan rancangan yang telah ditetapkan baik proses pencuciannya maupun penjemurannya. Lakukan uji ketahanan warna terhadap pencucian maupun katahanan terhadap sinar matahari menggunakan Grey Scal . Selanjutnya nilai yang ada dibandingkan dengan ketentuan yang ada menurut kriteria pada SNI. Hasil penelitian menunjukan kain batik yang dicuci menggunakan deterjen berulang mulai 5 kali telah memudar/luntur warnya. Semakin banyak konsentrasi deterjen yang digunakan dan semakin sering kain batik dicuci hingga 10 kali warna akan semakin memudar/luntur. Kain yang memudar warnanya akan sulit untuk dijual dipasaran.
\end{abstract}

Kata Kunci: konsentrasi deterjen, warna memudar, SNI .

\begin{abstract}
The study, entitled The Effect of Washing Detergent Concentration on the Quality of Batik Fabric, is aimed to find out whether there is an effect of detergent concentration on the quality of batik cloth and to what extent the resulting color changes. Furthermore, the quality of the resulting color is compared according to SNI criteria. Washing is carried out using batik detergent in accordance with predetermined concentrations. Batik cloth that has undergone a washing process using detergent in accordance with the concentration. The next batik cloth is dried by drying directly in the sun to dry. Repeat the experiment in accordance with the design that has been determined both the washing process and drying. Perform a color resistance test for washing and resistance to sunlight using Gray Scal. Furthermore, the existing value is compared with the existing provisions according to the criteria in SNI. The results showed batik cloth which was washed using detergent repeatedly starting 5 times has faded / warnya. The more the concentration of detergent is used and the more often batik cloth is washed up to 10 times the color will fade. Fabrics that fade in color will be difficult to sell on the market.
\end{abstract}

Keywords: detergent concentration, color fading, SNI.

\section{PENDAHULUAN}

Batik merupakan seni kerajinan yang menakjubkan warisan budaya nenek moyang bangsa Indonesia yang telah diakui oleh UNESCO . Seni kerajinan batik merupakan kreatifitas menghias kain dengan menggunakan lilin sebagai zat perintang dan zat pewarna [1]. Keberadaan kain batik hingga saat ini telah dikenakan hampir diseluruh masyarakat Indonesia. Kain batik saat ini dianggap sebagai pakaian semi resmi yang dapat digunakan dalam berbagai acara apapun, bahkan kain batik tidak hanya digunakan sebagai pakaian saja tetapi digunakan untuk keperluan yang lainnya dalam kehidupan .

Kain Batik menurut Badan Standarisasi Nasional Indonesia, secara garis besar pengertian batik adalah : suatu proses pewarnaan pada media apapun khususnya kain dengan menggunakan bahan perintang lilin (malam) panas, untuk menorehkannya menggunakan alat utama berupa canting tulis dan canting cap, membentuk motif dan bermakna. Jenis batik meliputi batik tulis, batik cap dan batik kombinasi cap dan tulis. Adapun "batik" printing sebenarnya itu bukan batik melainkan tekstil motif batik. Dalam prakteknya masyarakat awam masih sulit membedakan antara batik asli dan bukan batik. Peran edukasi batik sangat 
diperlukan dan dikembangkan, sehingga masyarakat tahu persis dengan apa yang disebut batik dan semakin mencintai karya budaya adiluhung bangsa Indonesia [2].

Begitu banyaknya masyarakat yang suka menggunakan kain batik, tetapi kemungkinan masih banyak pula masyarakat pengguna kain batik yang belum mengetahui bagaimana cara menjaga kualitas warna kain batik tersebut bisa bertahan lama. Anggapan masyarakat pada umumnya bahwa kain batik dikatakan berkualitas apabila kain batik tersebut warnanya tidak berubah atau tidak luntur walau telah dilakukan pencucian berulang-ulang. Salah satu cara untuk menjaga kualitas warna kain batik tersebut dapat bertahan lama adalah dengan memperhatikan kondisi proses pencucian setelah kain batik digunakan. Seperti diketahui bersama bahwa kebanyakan masyarakat untuk mencuci pakaian yang kotor apapun itu jenis pakaiannya digunakan deterjen atau sabun, termasuk didalamnya untuk mencuci pakaian kain batik kotor

Pada umumnya masyarakat untuk melakukan proses pencucian kain kotor pemakaian jumlah deterjen untuk mencuci hanya tidak diperhatikan betul biasanya hanya berdasrkan perkiraan.. Apabila air pencuci yang ada menimbulkan busa yang melimpah maka penggunaan deterjen dianggap sudah cukup dan kain hasil cucian akan dianggap bersih dan sebaliknya, apabila busa yang ditimbulkan sedikit maka dianggap deterjen yang digunakan kurang. Apabila busa yang ditimbulkan sedikit maka untuk memperbanyak busa harus ditambah dengan deterjen lagi . Penambahan deterjen biasanya dilakukan dengan cara kira-kira hingga busa yang ditimbulkan cukup banyak. Biasanya masyarakat tidak mempedulikan akan pengaruh jumlah deterjen yang digunakan terhadap kualitas warna kain hasil pencucian. Masyarakat hanya melihat bahwa apabila busa cucian melimpah maka kain hasil cucian menjadi bersih, biasanya masyarakat tidak mempedulikan warna kain hasil cucian menjadi luntur atau tidak. Selanjutnya kain yang telah dicuci bersih dengan deterjen lalu dilakukan proses penjemuran dibawah sinar matahari.

Berdasarkan uraian tersebut di atas maka penulis tertarik untuk mengangkat judul penelitian Pengaruh Konsentrasi Deterjen Pencuci Terhadap Kualitas Kain Batik . Diharapkan hasil penelitian ini dapat mengetahui pada kondisi proses pencucian bagaimana warna kain batik tidak luntur dan pada kondisi bagaimana akan mulai luntur. Selanjutnya kualitas kain hasil pencucian tersebut dibandingkan dengan kriteria menurut SNI.

Rumusan Masalah

Berdasarkan uraian tersebut diatas maka, permasalahan yang akan diangkat dalam penelitian ini adalah :

1. Adakah pengaruh konsentrasi penggunaan deterjen pencuci terhadapkualitas warna kain batik untuk proses pencucian.

2. Pada kondisi proses bagaimanakah warna kain batik hasil pencucicn mulai luntur.

3. Sampai seberapa jauh kualitas warna kain batik hasil cucian tersebut apabila dibandingkan dengan SNI

Tujuan Penelitian

Berdasarkan uraian tersebut di atas maka tujuan penelitian yang dimasudkan adalah :

1. Untuk mengetahui pengaruh konsentrasi deterjen terhadap kualitas warna kain batik yang diproses pencucian dengan berbagai macam konsentrasi deterjen yang digunakan.

2. Untuk mengetahui kondisi proses pencucian yang warnanya mulai luntur

3. Untuk mengetahui sampai seberapa jauh kualitas warna kain batik yang dihasilkan apabila dibandingkan dengan SNI

\section{METODE PENELITIN}

\subsection{Tempat Penelitian}

Penelitian ini dilakukan Universitas Widya Mataram Yogyakrta.

\subsection{Bahan Penelitian}

a. Kain Batik

b. Deterjen Risno Anti Noda

2.3 Alat Penelitian

a. Ember Cuci

b. Gunting

2.4 Cara Penelitian

a. Siapkan kain batik yang akan dilakukan pencucian sesuai kebutuhan

b. Siapkan larutan sabun untuk pencucian.

c. Bilas hingga bersih

d. Jemur kain hingga kering.

e.Lakukan pengulangan pencucian kain batik sesuai dengan ketentuan yang 
d. Evaluasi masing - masing hasil pencucian dengan skala Greyscal

e. Bandingkan dengan SNI untuk ketahanan warna terhadap pencucian maupun sinar matahari

Tabel 1. Rancangan Percobaan

\begin{tabular}{|c|c|c|c|c|c|}
\hline No & $\begin{array}{c}\text { Konsentrasi Deterjen } \\
(\mathrm{gr} / 1)\end{array}$ & \multicolumn{3}{|c|}{ Frekuensi Pencucian } & \multirow{2}{*}{ Jumlah Percobaan } \\
\cline { 3 - 5 } & 1,00 & $5 \mathrm{x}$ & $7 \mathrm{x}$ & $10 \mathrm{x}$ & \\
\hline 1 & 1,50 & 3 & 3 & 3 & 9 \\
\hline 2 & 2,00 & 3 & 3 & 3 & 9 \\
\hline 3 & 2,50 & 3 & 3 & 3 & 9 \\
\hline 4 & & 3 & 3 & 9 \\
\hline
\end{tabular}

Pada rancangan percobaan ini untuk masing-masing konsentrasi deterjen yang digunakan misal penggunaan konsentrasi deterjen 1 gram/lt akan dilakukan proses pencucian hingga $5 \mathrm{x}$ pencucian untuk kain sebanyak 3 potong, masih dalam penggunaan konsetrasi 1 gram/lt ditempat yang lain dilakukan proses pencucian kain batik hingga 7 x pencucian untuk kain sebanyak 3 lembar. Begitu juga untuk penggunaan konsentrasi deterjen 1 gram/lt ditempat yang lain akan dilakukan proses pencucian hingga $10 \mathrm{x}$ pencucian untuk sebanyak kain 3 lembar. Sehingga untuk penggunaan deterjen dengan konsentrasi 1 gram /lt untuk berbagai macam pencucian dalam penelitian jumlah percobaannya sebanyak 9 percobaan. Begitu pula untuk percobaan selanjutnya untuk penggunaan konsentrasi deterjen yang berbeda sesuai tabel akan dilakukan proses pencucian seperti pada penggunaan konsentrasi deterjen 1 gram/lt. Sehingga untuk penggunaan konstrasi deterjen yang berbeda akan dilakukan percobaan masing-masing sebanyak 9 percobaan. Berikut alur penelitian ini dapat dilihat pada Gambar 1.

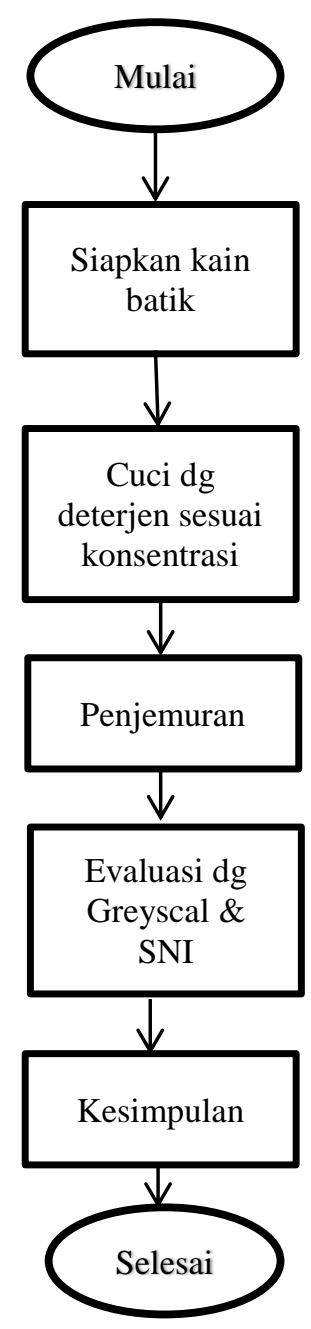

Gambar 1. Diagram Alir Peneltian 


\section{HASIL DAN PEMBAHASAN}

Penelitian tentang Pengaruh Konsentrasi Penggunaan Deterjen Terhadap Kualitas Kain Batik pada kali ini dipilih bahan kain batik cap yang dipakai sebagai bahan penelitian dibeli sembarangan di pasar dan dipilih dengan harga yang murah yaitu harga @ Rp 75.000,-/ potong. Pemilihan harga kain batik yang murah diharapkan dapat mewakili kualitas warna kain batik secara keseluruhan terhadap perubahan warna setelah kain tersebut mengalami beberapa kali pencucian dengan menggunakan berbagai macam konsentrasi deterjen dan beberakali pencucian. Apabila kain batik yang dipakai sebagai bahan penelitian dipilih dengan harga yang mahal dikhawatirkan tidak dapat mewakili kualitas warna untuk kain batik tersebut setelah mengalami pencucian berulang kali bila dibandingkan dengan harga murah. Kain batik dengan harga mahal tentu dikerjakan dengan proses yang lebih baik dan pemakaian zat pewarnanya juga dipilih zat pewarna yang lebih bagus kualitasnya sehingga hasil secara keseluruhan kain batik dengan harga mahal pasti mempunyai kualitas warna yang lebih bagus.

Pada penelitian ini untuk masing-masing kain batik yang telah dilakukan pencucian dengan larutan deterjen dengan berbagai macam konsentrasi lalu dibilas hingga bersih lalu dijemur hingga kering.. Selanjutnya kain dievaluasi untuk menentukan nilai perubahan warnanya menggunakan grey scale.Grey Scale adalah suatu alat untuk menentukan penilaian perubahan warna secara visual yang dilakukan dengan membandingkan perubahan warna kain yang terjadi dengan suatu standar warna yang ada [3]. Adapun pembagian nilai perubahan warna pada grey scale sebagai berikut :

Tabel 2. Perubahan Penilaian pada grey scale

\begin{tabular}{|c|c|c|}
\hline No & Nilai perubahan warna & Keterangan \\
\hline 1 & 1 & Jelek sekali \\
\hline 2 & 2 & Jelek \\
\hline 3 & 3 & Cukup \\
\hline 4 & 4 & Baik \\
\hline 5 & 5 & Baik sekali \\
\hline
\end{tabular}

Tabel 2: merupakan kualitas perubahan niali Grey Scale bahan uji suatu kain setelah mengalami proses tertentu . Pada grey scale ini perubahan warna dibagi menjadi 5 gradasi warna mulai yang paling pekat hingga warna yang ringan. Perubahan warna kain setelah mengalami suatu proses misal pencucian dibandingkan dengan kain yang belum mengalami proses pencucian, apabila perubahan warnaya sangat mencolok dalam hal ini masuk dalam gradasi warna gelap pada grey scale maka nilai perubahan adalah 1 (satu) sehingga kain tersebut kualitas warnanya jelek sekali dan sebaliknya apabila perubahan warna setelah pencucian sangat sedikit sekali sehingga warnapada grey scale perubahan warnanya ringan sekali maka nilai perubahan adalah 5 (lima) maka kain tersebut kualitas warnya bagus sekali.

Setelah nilai perubahan warna ditentukan selanjutnya nilai tersebut dibandingkan dengan SNI ISO 105-C05: 2010 [4], umtuk nilai ketahanan warna terhadap penjemuran / sinar matahari dan SNI ISO 105-C06 untuk ketahanan warna kain terhadap pencucian. Adapun pembagian penilaian dalam SNI ISO 105 - C06 : 2010[5] seperti pada tabel 4.2 sebagai berikut :

Tabel 3. Perubahan Penilaian Ketahanan Warna Terhadap Pencucian pada SNI ISO 105-C05 : Tahun 2010

\begin{tabular}{|c|c|c|c|}
\hline No & $\begin{array}{c}\text { Nilai Tahan luntur } \\
\text { warna }\end{array}$ & $\begin{array}{c}\text { \% Perbedaan } \\
\text { warnayang } \\
\text { timbul }\end{array}$ & Keterangan \\
\hline 1 & 5 & 0 & Baik sekali \\
\hline 2 & $4-5$ & 0,8 & Baik \\
\hline 3 & 4 & 1,7 & Baik \\
\hline 4 & $3-4$ & 2,5 & Cukup Baik \\
\hline 5 & 3 & 3,4 & Kurang \\
\hline 6 & $2-3$ & 4,8 & Jelek \\
\hline 7 & $2-1$ & 6,8 & Jelek sekali \\
\hline 8 & 1 & 13,6 & \\
\hline
\end{tabular}


Tabel 3 merupakan kualitas nilai yang disyaratkan dalam SNI ISO 105-C05 Tahun 2010 untuk kualitas perubahan warna kain setelah mengalami proses pencucian. Pada SNI ini kualitas perubahan warna kain bibagi memjadi 8 (delapan) kriteria, kriteria yang ke1 (satu) dalam hal ini kain setelah mengalami pencucian tidak mengalami perubahan warna dan diberi nilai 5(lima) karena \% perbedaan warna yang timbul hampir 0 (nol) sehingga kualitas warna kain tersebut masuk dalam kategori bagus sekali. Selanjutnya untuk kualitas warna yang termasuk jelek sekali dengan nilai 1(satu) apabila terjadi perubahan warna setelah pencucian hingga 13,6\% dibandingkan dengan warna sebelum proses pencucian .

Tabel 4. Penilaian Ketahanan Warna Terhadap Sinar Matahari pada SNI ISO 105-C06 : Tahun 2010

\begin{tabular}{|c|c|c|c|}
\hline No & $\begin{array}{c}\text { Nilai Tahan luntur } \\
\text { warna }\end{array}$ & $\begin{array}{c}\text { Perbedaan } \\
\text { warna }\end{array}$ & Keterangan \\
\hline 1 & 5 & 0 & Baik sekali \\
\hline 2 & $4-5$ & 0,8 & Baik \\
\hline 3 & 4 & 1,7 & Baik \\
\hline 4 & $3-4$ & 2,5 & Cukup Baik \\
\hline 5 & 3 & 3,4 & Cukup \\
\hline 6 & $2-3$ & 4,8 & Jelek \\
\hline 7 & $2-1$ & 6,8 & Jelek sekali \\
\hline 8 & 1 & 13,6 & \\
\hline
\end{tabular}

Tabel 4 merupakan kualitas nilai yang disyaratkan dalam SNI ISO 105-C06 Tahun 2010 untuk kualitas perubahan warna kain terhadap ketahanan terhadap sinar matahari ( penjemuran). Pada SNI ini kualitas perubahan warna kain terhadap ketahanan sinar matahari (penjemuran) bibagi memjadi 8 (delapan) kriteria, kriteria yang ke1 (satu) dalam hal ini kain setelah mengalami penjemuran tidak mengalami perubahan warna dan diberi nilai 5(lima) karena \% perbedaan warna yang timbul hampir 0(nol) sehingga kualitas warna kain tersebut masuk dalam kategori bagus sekali. Selanjutnya untuk kualitas warna yang termasuk jelek sekali dengan nilai 1(satu) apabila terjadi perubahan warna setelah pencucian hingga 13,6 \% dibandingkan dengan warna sebelum proses baik pencucian pencucian dan penjemuran.

\subsection{Kualitas Warna Kain Batik Setelah Proses Pencucian}

Berikut adalah perubahan warna kain batik setelah mengalami pencucian dengan berbagai macam konsentrasi deterjen dapat dilihat pada gambar berikut :

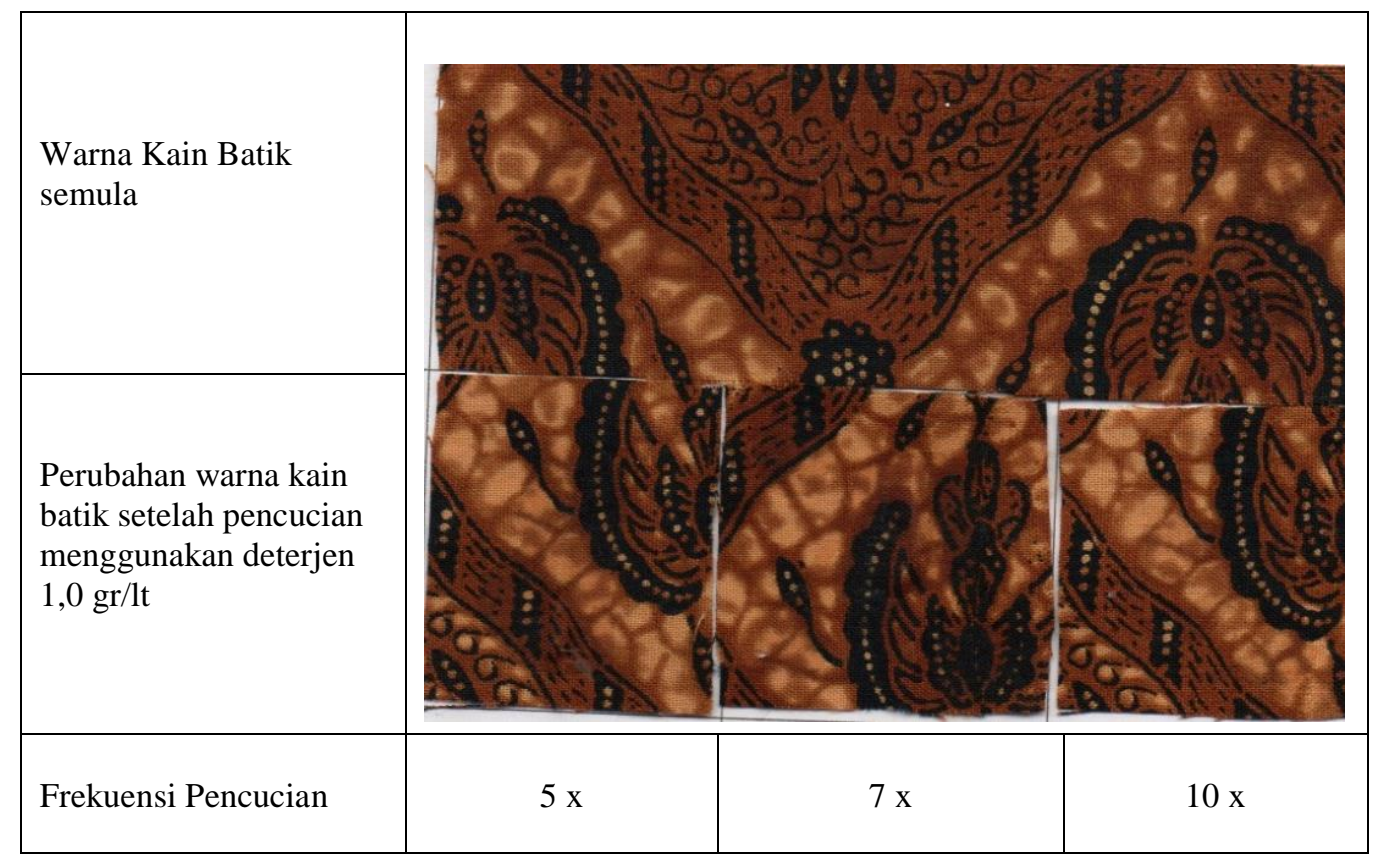

Gambar 2. Kualitas warna kain batik setelah mengalami proses pencucian menggunakan deterjen 1,0 gr/lt 


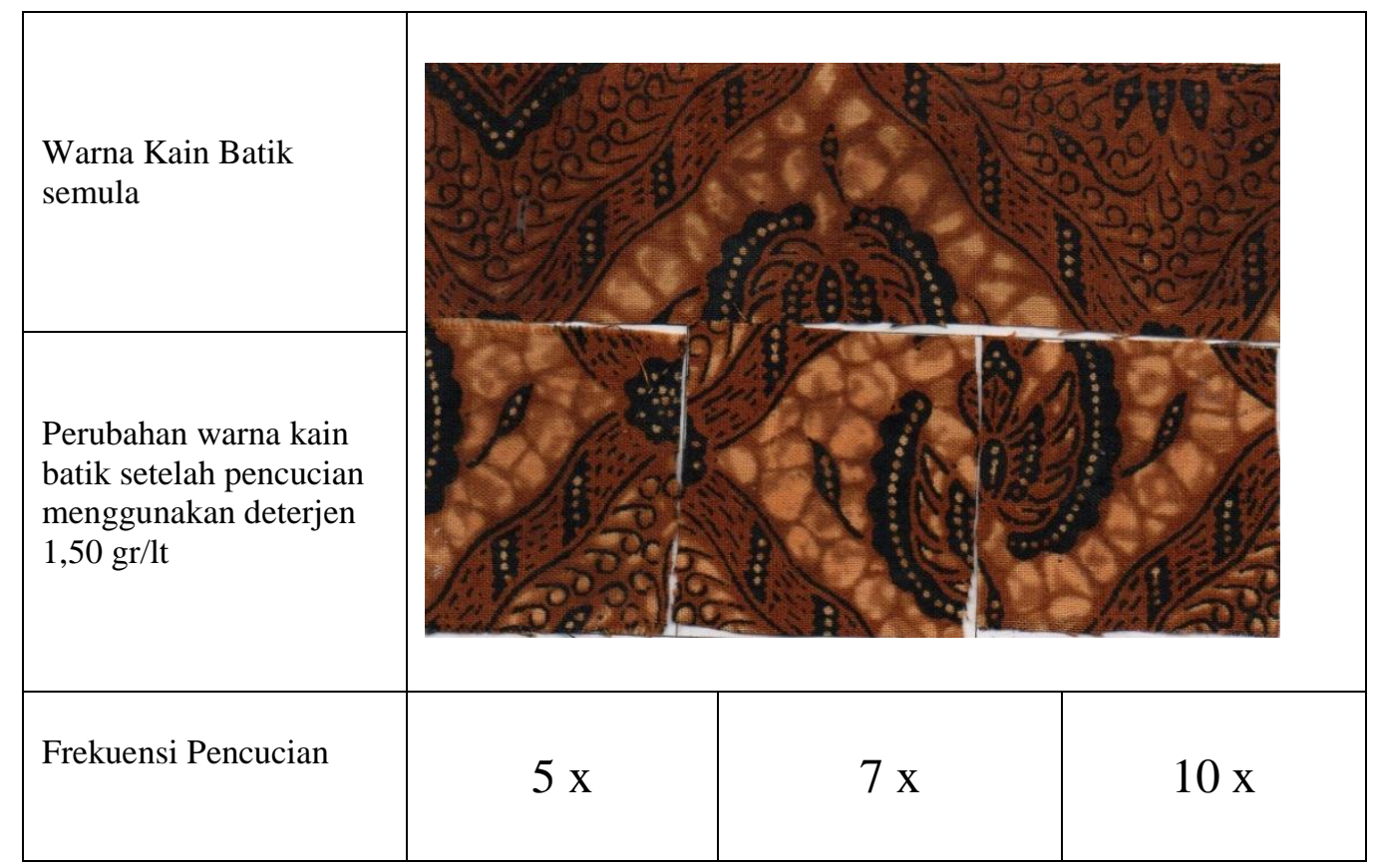

Gambar 3. Kualitas warna kain batik setelah mengalami proses pencucian menggunakan deterjen $1,50 \mathrm{gr} / \mathrm{lt}$

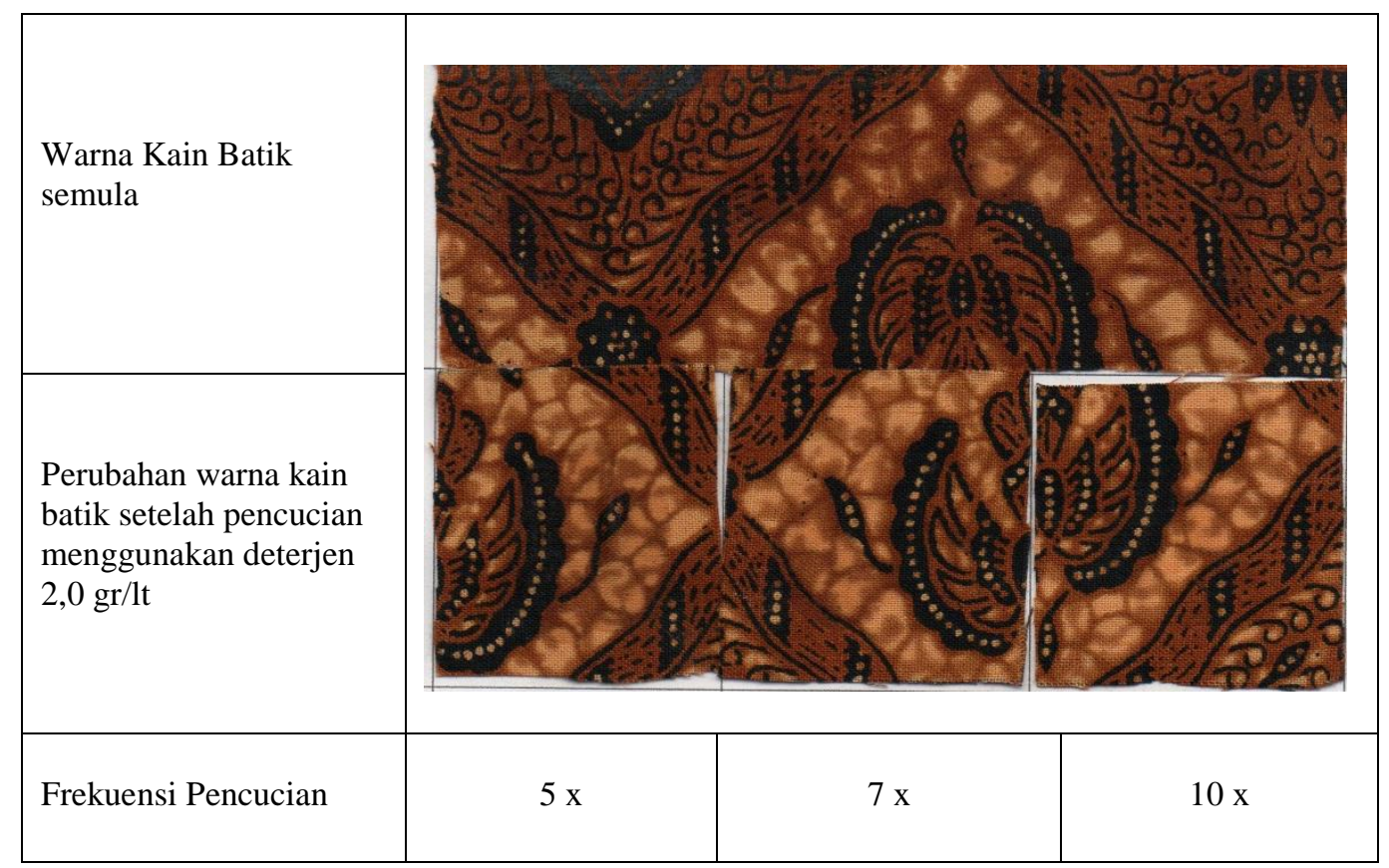

Gambar 4. Kualitas warna kain batik setelah mengalami proses pencucian menggunakan deterjen $2,0 \mathrm{gr} / \mathrm{lt}$ 


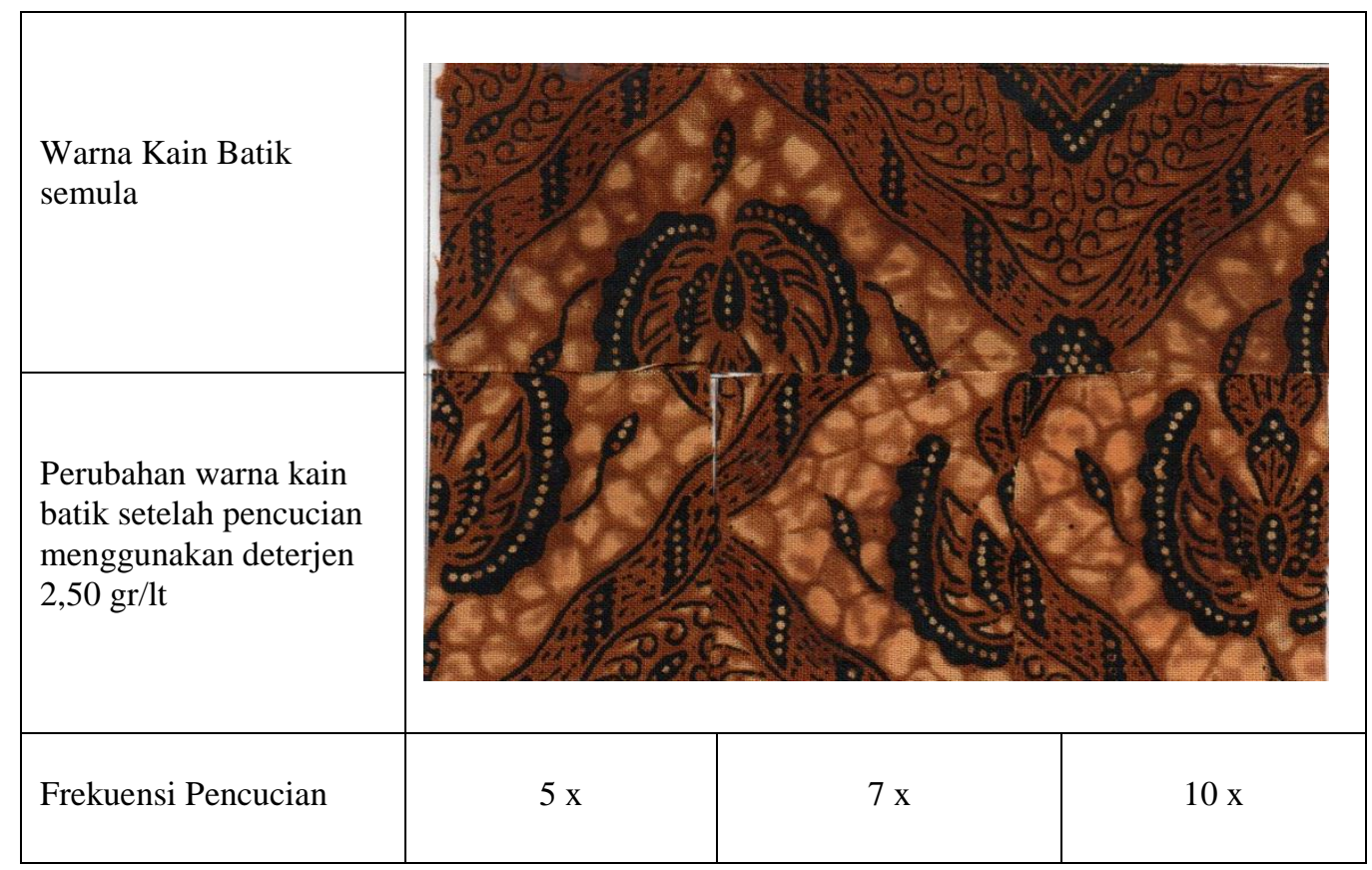

Gambar 5. Kualitas warna kain batik setelah proses pencucian menggunakan deterjen $2,50 \mathrm{gr} / \mathrm{lt}$

\subsection{Nilai Ketahanan Warna Terhadap Pencucian}

Berikut adalah nilai uji ketahanan warna kain batik terhadap pencucian menggunakan berbagai macam konsentrasi deterjen dan frekuensi pencucian dapat dilihat dengan jelas pada tabel 4.4 sebagai berikut :

Tabel 5. Nilai Uji Ketahanan warna terhadap Pencucian

\begin{tabular}{|c|c|c|c|c|}
\hline \multirow{2}{*}{$\begin{array}{c}\text { Konsentrasi } \\
\text { Deterjen (gram/lt) }\end{array}$} & \multicolumn{4}{|c|}{ Frekuensi Pencucian } \\
\hline Kain semula & 3 & $5 \mathrm{x}$ & $7 \mathrm{x}$ & $10 \mathrm{x}$ \\
\hline 1,0 & & & & $4-5$ \\
\hline 1,50 & & $3-4$ & 4 & 4 \\
\hline 2,0 & & 3 & $3-4$ & 4 \\
\hline 2,50 & & 3 & $3-4$ & 4 \\
\hline
\end{tabular}

\subsection{Nilai Ketahanan Warna Terhadap Sinar Matahari.}

Berikut adalah nilai uji ketahanan warna kain batik terhadap pencucian menggunakan berbagai macam konsentrasi deterjen dan frekuensi pencucian dapat dilihat dengan jelas pada tabel 4.4 sebagai berikut :

Tabel 6. Nilai Uji Ketahanan warna terhadap Sinar Matahari

\begin{tabular}{|c|c|c|c|c|}
\hline \multirow{2}{*}{$\begin{array}{c}\text { Konsentrasi } \\
\text { Deterjen (gram/lt) }\end{array}$} & \multicolumn{4}{|c|}{ Frekuensi Pencucian Dan Penjemuran } \\
\hline Kanpa Dicuci & $5 \mathrm{x}$ & $7 \mathrm{x}$ & $10 \mathrm{x}$ \\
\hline Kain semula & 3 & & 4 & $4-5$ \\
\hline 1,0 & & $3-4$ & $3-4$ & 4 \\
\hline 1,50 & & 3 & $3-4$ & 4 \\
\hline 2,0 & & 3 & $3-4$ & 4 \\
\hline 2,50 & & 3 & & \\
\hline
\end{tabular}




\subsection{Perubahan Kualitas Warna Kain Batik Setelah Proses Pencucian Dengan Berbagai Macam Konsentrasi Deterjen}

Berdasarkan gambarb 3.1 dapat dilihat dengan jelas bahwa warna kain batik setelah mengalami pencucian dengan konsentrasi deterjen 1,0 gram/liter pada pencucian selama 5 kali dan warna kain batik telah memudar/luntur warnanya dan warna akan semakin memudar setelah kain batik mengalami pencucian 10 kali . Pada penelitian ini setiap proses pencucian selanjutnya kain batik dibilas dengan air bersih sebanyak 3 kali hal ini dilakukan dengan harapan semoga kain batik hasil cucian betul-betul bersih. Untuk proses pencucian yang pertama kali ( frekuensi ke 1) kain batik sudah memudar/luntur warnanya, ini dapat dilihat pada saat pencucian warna air cucian terutama air dengan deterjen akan berwarna sangat kuat sesuai dengan warna kain batik yang ada, selanjutnya air bilasan yang pertama masih berwarna sesuai dengan warna kain batik yang ada tetapi warnya tidak sekuat pada air deterjen semula. Air bilasan yang kedua sudah semakin berkurang dan bilasan yang ke 3 menjadi semakin bening atau semakin bersih. Pada pencucian frekuensi yang ke 2 pada saat kain batik terkena larutan deterjen warna kain akan luntur tapi tidak sekuat pada pencucian frekuensi yang pertama. Air bilasan pertama pada pencucian ini masih berwarna tapi tidak sekuat pada warnanya pada saat terkena larutan deterjen, begitu pula air bilasan yang pertama air bilasan sedikit berwarna dan untuk bilasan yang ke 2 dan yang ke 3 warna air bilasan sudah bening. Selanjutnya pada pencucian pada frekuensi yang ke 3 larutan deterjen hanya sedit berwarna dan untuk proses pembilasan selanjutnya baik bilasan yang pertama maupu yang ke 3 air bilasan sudah berwarna bening ini berarti warna tidak luntur lagi . Untuk pencucian pada frekuensi ke 4 dan seterusnya warna air cucian baik warna air larutan deterjen maupun warna air bilasan sudah bening tidak berwarna. Begitu selanjutnya semakin banyak konsentrasi deterjen yang digunakan untuk memcuci, maka warna air pada larutan deterjen akan semakin kuat. Warna pada larutan deterjen semakin kuat ini artinya bahwa pewarna yang ada pada kain batik semakin banyak yang terlaut dengan deterjen sehingga warna akan kain batik akan semakin melemah atau warna kain batik akan menjadi luntur. Semakin banyak konsentrasi deterjen yang digunakan maka zat pewarna pada kain batik akan semakin banyak yang terlarut dan luntur. Semakin banyak konsentrasi deterjen yang digunakan untuk mencuci dan semakin sering kain batik tersebut di lakukan pencucian maka kain batik tersbut akan semakin melemah warnaya / memudar/luntur.

Berdasarkan gambar 3.1 hingga gambar 3.4 dapat dilihat dengan jelas bahwa semakin banyak deterjen yang digunakan maka warna akan semakin memudar/warna semakin melemah begitu pula pada kain batik yang semakin sering dicuci maka warna kain batik juga akan semakin melemah/luntur. Hal ini dapat dijelaskan , bahwa sifat zat pewarna Napthol akan mudah larut dalam alkali semakin pekat alkali yang digunakan maka zat pewarna Napthol akan semakin mudah larut. Pada penelitian ini karena zat pewarna yang digunakan pada kain batik tersebuat menggunakan zat pewarna Napthol dan sesuai dengan sifat zat pewarna Napthol yang tidak tahan terhadap alkali/sabun sehingga warna yang ada akan larut dalam air deterjen/sabun. Semakin banyak konsentrasi deterjen yang digunakan maka kelarutan zat pewarna yang ada akan semakin banyak. Apalagi semakin kain batik tersebut dicuci berulang kali ini berarti semakin sering zat pewarna kain batik akan semakin larut dan ini berarti warna kain batik yang ada akan semakin melemah luntur.

Berdasarkan data tabel 3.4 dapat dilihat dengan jelas bahwa ketahanan warna terhadap pencucian maka, semakin banyak konsentrasi deterjen yang digunakan untuk mencuci maka nilai ketahanan luntunya akan semakin besar. Menurut tabel 3.3 menjelaskan bahwa nilai ketahan 3 artinya bahwa kain tersebut untu ketahanan terhadap pencucian hanya bersifat cukup, sedangkan pada pemakaian deterjen untuk mencuci konsentrasi 1.0 gram/lt nilai ketahanan lunturnya terhadap pencucian adalah 3-4. Nilai ketahanan luntur $3-4$ mempunyai arti bahwa ketahanan cuci kain tersebut cukup baik. Untuk kain batik yang mengalami proses pencucian dengan deterjen lebih dari 5 kali akan mempunyai nilai ketahanan luntur $4-5$ ini artinya kain tersebut ketahanan lunturnya akan semakin baik. Semakin sering kain tersebut dicuci menggunakan deterjen, maka zat pewarna yang ada akan semakin banyak yang sudah terlarut dan yang tertinggal pada kain akan semakin sedikit. Zat pewarna yang ada dalam kain yang hanya semakin sedikit apabila dilakukan proses pencucian lagi maka tidak akan luntur lagi sehingga nilai ketahanan lunturnya akan menjadi lebih bagus. Nilai ketahanan lunturnya $4-5$ artinya baik tetapi kenyataannya warna kain batik yang ada sudah sangat lemah sehingga sulit untuk dijual sbagai produk unggulan. Walaupun nilai ketahanan terhadap pencucian menurut SNI ISO 105-C06 : 2010 termasuk baik karena tidak akan mewarnai cucian yang lainnya, tetapi karena warna akhir akan menjadi lemah tidak tajam lagi maka kain tersebut akan mempengaruhi pemakainya. Biasanya orang senang memakai pakaian yang mempunyai warna tajam/kuat, kalau warna pakain sudah lemah biasanya pakain tersebut sudah tidak akan dipakai lagi .Pakaian tersebut hanya untuk dipakai dirumah saja sebagai baju santai dirumah bukan baju kerja atau baju acara resmi, biasanya orang akan malu memakai pakaian yang sudah lemah warnanya untuk kerja apalagi untuk menghadiri acara resmi. 


\subsection{Ketahanan Warna Terhadap Sinar Matahari/ Penjemuran}

Berdasarkan data tabel 3.5 maka nilai ketahanan luntur terhadap sinar matahari atau penjemuran , mempunyai nilai yang sama terhadap ketahahan luntur terhadap pencucian . Pada pencucian dengan menggunakan deterjen dengan konsentrasi 1 gram/liter pada penjemuran 5 kali nilainya 3 - 4 , begitu pula nilai ketahanan lunturnya terhadap sinar matahari adalah $3-4$. Ini artinya bahwa kain batik pada saat dicuci dengan deterjen hingga dicuci sampai 5 kali zat pewarna yang ada dari kain batik terlarut pada larutan deterjen dan pada waktu dikenakan sinar matahari langsung ( dijemur) zat warna yang ada tidak tahan terhadap sinar matahari sehingga warna akan memudar /luntur . Pada kondisi pencucian lebih dari 5 kali nilai ketahanan luntur menjadi lebih baik yaitu 4 ini artinya bahwa zat pewarna yang ada pada kain batik pada waktu di cuci masih larut dalam larutan deterjen tetapi zat warna yang terlarut lebih sedikit dibandingkan pada waktu pencucian hingga 5 kali begitu juga pada waktu dijemur zat warna kain batik tersebut akan memudar lagi. Penurunan kualitas warna pada kain batik berdasarkan data tabel 3.1semakin kain batik dicuci berulang kali dalam hal ini hingga 10 kali maka kualitas warna kain batik semakin memudar/melemah walaupu nilainya $4-5$. Hal ini dapat di jelaskan bahwa kain batik bahwa semakin lemah warna kain batik seperti pada gambar 3.1 karena zat pewarna yang ada pada kain batik telah larut terlebih dahulu pada waktu proses pencucian menggunakan deterjen. Seperti diketahui bahwa zat pewarna Napthol juga mempunyai sifat yang tidak tahan terhadap sinar matahari sehingga kain batik yang sering dicuci dan dijemur berulangkali pada sinar matahari langsung akan memudarkan warna yang ada sehingga warna akan semakin memudar/ melemah/luntur. Berdasarkan gambar 4.2 warna kain batik yang dicuci berulang hingga 10 kali maka, ini artinya bahwa kain batik tersebut juga mengalami penjemuran sebanyak 10 kali maka warna yang dihasilkan akan sangat berbeda dengan warna kain batik sebelum dicuci atau kain batik yang di dicuci 5 kali atau penjemuran sebanyak 5 kali. Semakin sering dicuci dan dijemur maka kain batik tersebut akan semakin memudar warnanya. Begitu pula semakin banyak konsentrasi deterjen yang digunakan maka zat pewarna yang ada pada kain batik akan semakin banyak yang sudah terlarutkan selanjutnya kain batik dijemur berulang kali maka warna yang ada akan semakin memudar.

\subsection{Zat Pewarna Napthol untuk mewarnai kain batik .}

Kain batik sebagai bahan penelitian ini kebetulan menggunakan zat pewarna jenis napthol. Sesuai dengan sifat utama zat pewarna napthol bahwa napthol kurang tahan terhadap suasana alkali , dan tidak tahan terhadap sinar matahari sehinggga semakin pekat konsentrasi larutan sabun yang digunakan untuk mencuci dan semakin sering kain tersebut dicuci maka warna kain tersebut akan semakin memudar atau rusak [6] . Zat pewarna napthol selain tidak tahan alkali, zat warna tersebut juga mempunyai sifat daya affinitas terhadap serat rendah sehingga mudah bermigrasi pada saat dicuci sehingga hasil celupan sering tidak merata. Sesuai dengan sifat zat pewarna napthol yang ada maka napthol mepunyai sifat yang mudah digunakan dan murah harganya.

Zat pewarna lain yang dapat digunakan untuk mewarnai kain batik adalah zat pewarna indigofera, zat pewarna ini mempunyai warna yang tajam dan tahan terhadap pencucian maupun sinar matahari dan mudah digunakan. Karena kebaikan zat pewarna tersebut bila dibandingkan dengan zat pewarna napthol, maka zat pewarna indigofera harganya lebih mahal dibanding dengan zat pewarna napthol sehingga zat pewarna indigofera biasanya hanya digunakan untuk kain batik dengan harga jual yang mahal. Sedangkan zat warna napthol biasanya digunakan untuk kain batik dengan harga menengah kebawah.Untuk memperbaiki zat pewarna napthol agar mempunyai daya ketahan yang baik terhadap pencucian, penjemuran, dan gosokan dan yang lainnya biasanya kain setelah proses pewarnaan selesai dilakukan proses fiksasi

\section{6 . Proses fiksasi pada kain batik untuk memperbaiki Kualitas}

Kualitas warna pada kain batik selain dipengaruhi oleh sifat zat pewarna yang digunakan , juga dipengaruhi oleh proses berikutnya yaitu yang disebut proses fiksasi yang dilakukan pada kain tersebut. Proses fiksasi dilakukan setelah kainbatik selesai mengalami proses pewarnaan,dan sebelum proses pencucian dilakukan. Adapun tujuan dilakukan proses fiksasi ini adalah untuk mendapatkan warna yang tidak mudah bermigrasi alias luntur pada waktu proses pencucian [7]. Proses fiksasi dilakukan dengan menambahkan zat tertentu yang dapat menambah kekuatan ikatan antara serat kain dengan zat pewarna karena terjadi ikatan yang lebih kuat antara serat dengan zat pewarna sehingga zat pewarna yang ada menjadi lebih sulit untuk bermigrasi keluar/ luntur terikat kuat dengan serat kain . Apabila zat pewarna terikat kuat dengan serat yang ada , maka zat pe warna terserbut akan menjadi tahan terhadap pencucian, penjemuran, gosokan dan lain sebagainya. Dengan kata lain bahwa kualitas kain yang telah dilakukan proses fiksasi maka zat pewarnya akan tidak mudah lepas dari kain sehingga akan tahan terhadap pencucian, penjemuran, gosokan dan lain-lain. 
Dalam Kamus Besar Bahasa Indonesia, kualitas didefinisikan sebagai tingkat baik buruknya sesuatu. Kualitas dapat pula didefinisikan sebagai tingkat keunggulan, sehungga kualitas merupakan ukuran relatif kebaikan. Kualitas produk dan jasa didefinisikan sebagai keseluruhanh gabungan karakteristik produk dan jasa yang dihasilkan dari pemasaran, rekayasa, produksi dan pemeliharaan yang membuat produk dan jasa tersebut dapat digunakan untuk memwnuhi harapan pelanggan atau konsumen

Menurut Wignjosoebroto [8] yang dimaksud dengan kualitas adalah derajat dimana produk atau jasa tersebut mampu memuaskan keinginan dari konsumen (fitness for use atau taylormade).

Kualitas merupakan suatu kondisi dinamis yang berhubungan dengan produk, jasa, manusia, proses dan lingkungan yang memenuhi atau melebihi harapan [9].

Kualitas adalah gabungan keseluruhan karakteristik produk dan jasa dari segi pemasaran, rekayasa, pembuatan, dan pemeliharaan yang mana produk dan pelayanan tersebut dalam penggunaannya dapat memenuhi harapan-harapan konsumen (Feigenbaum, 1992). Juan mengartikan kulitas sebagai cocok/sesuai untuk digunakan (fitness for use) yang mengandung pengertian bahwa suatu produk atau jasa harus dapat memenuhi apa yang diharapkan oleh para pemakainya. Pengertian cocok untuk digunakan mengandung 5 dimensi utama, yaitu kualitas desain, kualitas kesesuaian, ketersediaan, keamanan, dan field use [9].

Kualitas warna pada kain batik selain dipengaruhi oleh sifat zat pewarna yang digunakan , juga dipengaruhi oleh proses berikutnya yaitu yang disebut proses fiksasi yang dilakukan pada kain tersebut. Proses fiksasi dilakukan setelah kainbatik selesai mengalami proses pewarnaan,dan sebelum proses pencucian dilakukan. Adapun tujuan dilakukan proses fiksasi ini adalah untuk mendapatkan warna yang tidak mudah bermigrasi alias luntur pada waktu proses pencucian [6]. Proses fiksasi dilakukan dengan menambahkan zat tertentu yang dapat menambah kekuatan ikatan antara serat kain dengan zat pewarna karena terjadi ikatan yang lebih kuat antara serat dengan zat pewarna sehingga zat pewarna yang ada menjadi lebih sulit untuk bermigrasi keluar/ luntur terikat kuat dengan serat kain. Apabila zat pewarna terikat kuat dengan serat yang ada , maka zat pe warna terserbut akan menjadi tahan terhadap pencucian, penjemuran, gosokan dan lain sebagainya. Dengan kata lain bahwa kualitas kain yang telah dilakukan proses fiksasi maka zat pewarnya akan tidak mudah lepas dari kain sehingga akan tahan terhadap pencucian, penjemuran, gosokan dan lain-lain.

Secara keseluruhan berdasarkan gambar 3.1, gambar 3.2 dan data tabel 3.4 maupun data data tabel 3.5, untuk menentukan kualitas warna kain tersebut layak untuk dijual atau dapat diterima oleh masyarakat harus memperhatikan: Kenyataan kualitas warna yang ada setelah dilakukan proses pencucian dan penjemuran yang berulang- ulang. Kualitas warna kain batik yang telah mengalami proses pencucian berulang-ulang dan memakai deterjen dengan konsentrasi yang berbeda-beda baik batik A atau kain batik B semuanya warna akan memudar warna menjadi sangat lemah luntur. Semakin tinggi pemakaian konsentrasi deterjen dan semakin sering dilakukan proses pencucian sehingga kualitas warna akan semakin memudar luntur. Sifat menurunnya kualitas warna setelah mengalami proses pencucian dengan deterjen ini sesuai dengan sifat zat pewarna yang ada yang tidak tahan terhadap kostik maka akan mudah luntur warna mudah bermigrasi keluar. Kain yang mudah luntur pada waktu dilakukan proses pencucian sehingga warnanya akan melemah maka akan sangat sulit untuk bisa diterima oleh masyarakat pasar. Masyarakat apabila mau membeli bahan pakaian pasti akan memilih yang berkualitas bagus diantaranya tidak mudah luntur apabila dicuci. Bahan pakain dikatakan berkualitas apabila bahan tersebut bisa memenuhi semua kriteria yang disyaratkan berdasarkan kriteria SNI ISO 105-C05 : 2010 untuk uji ketahanan warna terhadap pencucian dan SNI ISO 106-C06 :2010 uji ketahanan warna terhadap sinar matahari pada penjemuran langsung dibawah sinar matahari. Kain yang dikatakan berkualitas apabila tidak berubah warna maupun dimensinya setelah mengalami proses pencucian maupun penjemuran lamngsung dibawah sinar matahari serta tahan terhadap proses gosokan seterika.

\section{Simpulan}

Berdasarkan hasil analisi di atas maka dapat disimpulkan sebagai berikut:

1. Konsentrasi penggunaan deterjen pencuci berpengaruh terhadap kualitas warna kain batik

2. Pada pencucian yang diulang hingga 5 kali warna kain bati yang ada sudah mengalami memudar/luntur warnanya.

3. Warna kain batik akan memudar/luntur hingga nilai ketahanan lunturnya stabil pada pencucian yang diulang 10 kali.

\section{Saran}

1. Untuk perawatan kain batik agar warna tahan lama terutama kain batik yang diwarnai dengan zat pewarna Napthol maka untuk proses pencucian larutan sabun yang digunakansebaiknya yang ringan saja, jangan terlalu banyak sabun 
2. Untuk mempercepat proses pengeringan kain batik tersebut dapat dilakukan penjemuran dibawah terik matahari tetapi jangan terlalu lama bila sudah kering segera diangkati untuk dimasukan diruang yang teduh

\section{DAFTAR PUSTAKA}

[1] Susanto, Sewan, 1983. Seni Kerajinan Batik Indonesia, Balai Penelitian Batik Dan Kerajinan, Yogyakarta.

[2] Priyatmono. 2015. Workshop Sistem Produksi Hijau. Prodi Teknik Industri Universitas Muhammadiyah, Surakarta.

[3] Anonimus , 2010 , Badan Standar Nasional . ( 2010 ). Penetapan Nilai pada Grey Scale.

[4] Anonimus , 2010, Badan Standar Nasional . ( 2010a ). Tekstil - Cara Uji tahan luntur warna - bagian B01 : Tahan luntur warna terhadap Sinar Matahari In SNI ISO 105 - B01. Jakarta.

[5] Anonimus , 2010 , Badan Standar Nasional . ( 2010b ). Tekstil - Cara Uji tahan luntur warna - bagian C06 : Tahan luntur warna terhadap Pencucianrumah tangga. In SNI ISO 105 - B01. Jakarta.

[6] Jufri Rasyid. 1996, Teknologi Pengelantangan, Pencelupan dan Pencapan, Sekolah Tinggi Teknologi, Bandung.

[7] Isminingsih, 1994, Pengantar Kimia Zat Warna, Sekolah Tinggi Teknologi, Bandung.

[8] Wignjosoebroto, Sritomo, 2003, Pengantar Managemen Industri, Edisi 1, Guna Widya, Surabaya.

[9] Tjiptono, Fandy dan Diana, Anastasia, 2001, Total Quality Management, Edisi Revisi, Andy Offset, Yogyakarta. 